BOITO JR, Armando; GALVÃO, Andréa (Orgs). Política e classes sociais no Brasil nos anos 2000. São Paulo: Ed. Alameda, 2012. 429p.

\section{Tatiana Berringer}

Qual a relação dos movimentos sociais e sindicais com o governo Lula? Como a política estatal contribuiu para o retorno do crescimento econômico? Qual é o conflito de classes existente hoje no Brasil?

De maneira original e muito rigorosa, o livro Política e classes sociais no Brasil dos anos 2000 procura responder parte destas questões. Ao reunir nove artigos de membros do grupo Neoliberalismo e relações de classe no Brasil, sediado no Centro de Estudos Marxistas (CemarxUnicamp), o livro busca sistematizar, em dois blocos, estudos sobre as classes dominantes, as classes médias e as classes populares. Os autores tratam o conflito de classes como uma luta pela distribuição da riqueza e não como uma disputa entre capitalistas e socialistas, pois entendem que esse tipo de disputa não está colocada na atual conjuntura política e econômica.

Neste sentido, reconstituíram alguns elementos importantes do comportamento das classes médias e de frações das classes dominantes durante a década de 1990. Esta reconstituição nos permite perceber os elementos contraditórios que já se manifestavam nos governos anteriores e que foram rearticulados sob uma nova roupagem nos governos Lula (2003-2010). Mastuscelli defende que, apesar da raiz do processo do impeachmant do presidente Fernando Collor ter sido resultado da política econômica, foram os estudantes de classe média que ocuparam a função de agentes substitutos das classes burguesas e proletárias. Isso porque a burguesia brasileira estava acossada pela ofensiva imperialista e pelo forte movimento grevista de 1970 e 1980. Os autores afirmam que, durante o governo Collor, havia resistências seletivas às políticas neoliberais - manifestações corporativas - como as críticas da burguesia industrial ao aumento das importações e as críticas dos investidores aos confiscos dos ativos financeiros. Entretanto, as insatisfações destas frações das classes dominantes se deram, apenas, de maneira pontual (seletiva) e não se reverteram em uma oposição ao governo, pois, no geral, concordavam com as demais políticas neoliberais, em especial, a flexibilização das leis trabalhistas e o enxugamento da máquina estatal.

Para Boito Jr e Sávio Cavalcante, no governo Lula, o Estado convocou a burguesia brasileira a ter uma postura mais ativa. A nova burguesia brasileira (a burguesia interna) é uma fração que reúne diversos setores como grupos industriais, agronegócio, construção civil, minerações e outros. Através do apoio e do financiamento do BNDES, o governo fortaleceu esta fração no interior do bloco no poder em contraposição ao capital financeiro. Esta fração é a força dirigente da frente neodesenvolvimentista que abarca, também, o movimento popular e sindical. Ou seja, com a ascensão do Lula ao cargo de presidente do Brasil, em 2003, muita coisa mudou. Não tanto quanto esperava parte do eleitorado e, em especial, alguns integrantes do próprio PT e muitos intelectuais.

Durante o primeiro mandato, as análises acadêmicas (Leda Paulani, Chico de Oliveira, e outros) foram predominantemente negativas, acusava-se o governo de continuidade em relação ao antecessor, em função da manutenção do tripé econômico (superávit primário, juros altos e câmbio valorizado) e criticava-se a reforma da previdência dos servidores públicos e o assistencialismo das políticas sociais, em especial o Programa Fome Zero e o Bolsa Família.

A partir de 2005, após a chamada "crise do mensalão" e, especificamente, no segundo mandato do presidente Lula, as políticas neodesenvolvimentistas se tornaram mais intensas e, nesse sentido, o livro enfatiza a clara mudança entre os 
governos FHC e Lula, no que toca à política econômica e social. Cavalcante defende que o setor de telecomunicações é um bom exemplo do neodesenvolvimentismo no governo Lula. A fusão da Oi com a BrT, com o auxílio do BNDES, e o retorno da Telebrás no Plano Nacional de Banda Larga (PNBL) compõem parte da política de formação da "campeãs nacionais" e o retorno da participação de empresas estatais nos serviços públicos. As "campeãs nacionais" foram as empresas que receberam aportes do BNDES e dos fundos de pensão (Previ, Pretos, etc) para aquisição de novas empresas ou fusão com as concorrentes do ramo, com o objetivo de se tornarem líderes globais no seu segmento; por isso, a maioria destas empresas passou a atuar em outros territórios e passou a monopolizar o mercado interno no seu segmento.

Boito Jr adverte que o neodesenvolvimentismo é o desenvolvimento possível nos marcos no neoliberalismo. Segundo ele, o prefixo "neo" indica três grandes diferenças com o desenvolvimentismo do período de 1930-1980: 1) índices mais modestos de crescimento; 2) a aceitação da especialização regressiva, já que a produção se concentra em segmentos de baixa densidade tecnológica; 3) produção voltada para exportação. Para o professor, a eleição de Paulo Skaf, em 2004, para a presidência da Fiesp, com o apoio de Lula, foi uma inflexão na relação da entidade com o governo. Skaf relançou a Revista da Indústria e passou a criticar, com mais ênfase, a política de juros, o spread bancário, etc. Por isso, viu com bons olhos a troca de Palocci por Meireles no Banco Central, em 2005.

No que se refere às classes populares, o crescimento econômico trouxe consigo o aumento do número de empregos e do salário mínimo; com isso, houve uma aproximação das duas principais centrais sindicais - Força Sindical e CUT -, a retomada das greves e uma dificuldade de mobilização dos movimentos sociais, cujas bases eram, predominantemente, de desempregados. Por outro lado, a reforma sindical e a reforma da previdência contribuíram para a fusão de algumas antigas centrais e o surgimento de novas organizações como a
Conlutas e a Intersindical, estas duas organizações fazem oposição declarada ao governo, estando, respectivamente, ligadas ao PSTU e PSOL.

As políticas sociais, em especial o Programa Nacional de Habitação "Minha casa, minha vida", exerceram, também, um importante papel: atenderam parte das reivindicações dos movimentos de moradia e dos movimentos dos desempregados. Na realidade, Oliveira e Hirata demonstram que as famílias que mais se beneficiaram não estavam entre os $90 \%$ de renda de 0 a 3 salários mínimos, o que demonstra que, apesar de ser uma política que atendia aos reclamos dos movimentos de luta por moradia, não privilegiou, exatamente, a parcela mais necessitada.

As classes médias, sobretudo o setor com alta escolaridade, foram muito afetadas pelas políticas neoliberais, e, ao que parece, foram as que menos tiraram proveito do neodesenvolvimentismo. Não tiveram muitos ganhos salariais, não houve redução dos pagamentos dos serviços como educação, seguro de saúde, etc. E, sobretudo, os servidores públicos perderam direitos com a reforma da previdência. A principal manifestação destes setores nos anos 2000 foi o Fórum Social Mundial (FSM). Segundo Ana Elisa Corrêa e Santiane Arias, a sua base é, predominantemente, de classe média escolarizada e o conselho internacional é composto, predominantemente, por organizações não-governamentais, esses seriam os principais motivos para o caráter pouco propositivo e apartidário do FSM.

Pelo que se pode constatar da leitura do livro, há um limite e um desafio muito grande para a perpetuação do neodesenvolvimentismo no Brasil. O governo teria que aprofundar e modificar algumas políticas sociais, como o Programa Habitacional, a fim de atender à camada mais necessitada e, precisaria, ao mesmo tempo, conceder maiores ganhos às classes médias, sem que, para isso, os ganhos da burguesia interna sejam diminuídos. Não há como atender às demandas da burguesia interna como, por exemplo, a redução dos custos com a folha de pagamento, o aumento das terceirizações e, ao mesmo tempo, ter o apoio 
das classes médias e dos movimentos sindicais e melhor, disputam a distribuição dos recursos propopulares. Este é o limite da própria frente duzidos pelo crescimento econômico. Afinal de neodesenvolvimentista, os diferentes setores con- contas, não há como conciliar eternamente intecordam com a proteção ao mercado interno, o au- resses contraditórios.

mento do crédito, a redução dos juros, mas dis-

cordam em relação aos direitos trabalhistas, ou

Recebido para publicação em 07 de julho de 2013 Aceito em 30 de julho de 2013

Tatiana Berringer - Doutoranda em Ciência Política pela Universidade Estadual de Campinas. Integrante do grupo "Neoliberalismo e Relações de Classe no Brasil”, vinculado ao Centro de Estudos Marxistas (Cemarx) e do Grupo de Estudos e Pesquisas para Alternativas em Relações Internacionais (GARI) vinculado a UnespFranca. Pesquisa: Política Externa Brasileira; Teoria das Relações Internacionais; Teoria do Estado; Classes sociais. berringer.tatiana@gmail.com 
